\title{
Effect Of Globalization On Politics And Government: The Case Of Nigeria
}

\author{
Evwierhurhoma, Daniel Ejiroghene ${ }^{1}$ and Dr. E. Amah ${ }^{2}$ \\ Department of Management, Faculty of Management Sciences, University of Port Harcourt, Nigeria. \\ DOI: 10.29322/IJSRP.11.05.2021.p11349 \\ http://dx.doi.org/10.29322/IJSRP.11.05.2021.p11349
}

\begin{abstract}
Globalization has made the entire world to become a global village that has succeeded in integrating individuals, organizations as well as nation states. Over the years, globalization has increasingly integrated the globe as well helped in creating unity out of vast multiplicity of the world. Globalization affects every aspect of the society on a daily basis. Thus, this paper was able to critically examine the influence of globalization on the political environment as well on the government of Nigeria and its general implication on organization and managerial effectiveness and on the individual. The methodology used was qualitative methods through the review of literatures. From the discussion of findings, we concluded that globalization is very important to every government as well to every organization, this is because, no government is self-sufficient, no government can exist in a vacuum and no government is an island of itself, thus the need for integration brought by globalization. However Nigeria as a country have not been able to benefit from the process of globalization as it ought to due to corruptions, weak institutions and lack of governmental will to do what is right. We therefore, recommended among others that the government of Nigeria can benefit more from globalization by developing policies that will bring about improvement of the nation's competitive advantage in the global market by avoiding all kinds of foreign exploitation as well as all forms of corruptions at all level.
\end{abstract}

Index Terms- Globalization; Political Environment; Government; Nigeria

\section{INTRODUCTION}

$\mathrm{N}$ owadays, changes in economic and socio-cultural activities as well as changes in technology have altered the way countries as well as government behaves globally in terms of policies formulations as well as their executions and how they carried out their politics. This is brought about by globalization which has made the world of today to become a global village where one can sit at the comfort of his or her home and connect to any part of the world within a second. Today, everyone is everyone's neighbour globally to this effect what happen as far as Wuhan city in China could have impact in city such as Lagos in Nigeria. Globalization has become so important in today's world that it affects all aspect of the world politically, socially, economically, technologically and all aspects of life. The case of the current corona virus pandemic that broke out in Wuhan city in China has become the recent impact globalization can cause. Today, this pandemic has brought devastating consequences on countries all over the world politically, socially, economically, financially, technologically and in all aspects of life. Strongest world economies and the world political leaders are shaking to their toes because of the virus that broke out as far as Wuhan city in China. This implies that countries of the world today, are more connected, related and dependent than before.

Globalization today has turn out to be one of the most popular concepts frequently used in this $21^{\text {st }}$ century by almost everybody from all works of life. However, the term is very multifaceted and sometimes can be very confusing with influence not only covering economic but also covers the environment, government/political, geographical, social and the cultural terrain of every country. Thus, Scholte (2000) expressed that despite all the publications on globalization, its analysis have a tendency to continue to be imprecise conceptually, historically and empirically emaciated, normatively trivial as well politically naive. In order words, the meaning of globalization is very multifaceted and scholars from different discipline define it based on their discipline.

The United Nations Development Programme (1999) explain that the term globalization has to do with the interdependence of the world's people, combining the economy, culture, technology as well governance of different countries. It is the incorporation of independent state economies through trade and financial dealings. Due to globalization, governments everywhere have become more connected and more inter dependent than before so as to foster global peace and collective security interests. Since the 1990s globalization has turn out to be a particular way of analyzing changes in the global economy as well in the world politics (Majekodunmi and Adejuwon, 2012). Technological advancement as well as improvement in communications tools have brought about a new way individuals, organizations and governments interacts with one another with a speed of light. Thus the outcome according to Ngaire (2000) has influenced national and international politics in an amazing form.

According to Majekodunmi and Adejuwon (2012) globalization is a potent real aspect of the new world system, and it represents one of the most influential forces in determining the future course of the world. Definitely, the way at which globalization is spreading today, it cannot be resist by any individual, organization or government and whether government likes it or not, the activities of one government has a way of affecting one another, however globalization is often time bedeviled with various and different negative and positive reactions from both individuals and developing countries such as Nigeria. Most individuals and countries have seen it as a means of 
exploitation from the European developed countries as well as the United States of America while others have seen it as a means to interconnect with different countries for mutual benefits.

Over the years, globalization has changed how individuals and organization as well as government carry out their operations due to its effect on every aspect of the society of today's world. It influences how goods and services are produced as well their distributions, price policies, investment and technological adoption or distribution from one country to the other. It also affects the general performance of organizations, thus, Intriligator (2003) expressed that globalization plays an important role in enhancing efficiency as well as the productivity and the competitive capacity of the organization. Nevertheless, in today's world, lots of developing countries especially those in Africa are in serious debts notwithstanding they are experiencing globalization whereas other countries such as European countries and the US are taking real advantage of it in developing their countries more. Thus, African governments in general and Nigerian government specifically need to formulate and implement rules as well set up stronger institutions for better governance at local, national, regional and international levels to ensure that globalization yield the expected benefit.

Furthermore, Nigeria as a country has over the years acknowledged globalization as tool for national development. Ironically, with all the natural resources that Nigeria has, majority of her citizen are wallowing in abject poverty; according to the World Bank (2019), 46.5\% that is 91,885,874 Nigerians are living in abject poverty, in other words this number of persons lives below $\$ 1.90$ (that is about \#693.5) per day. More so, according to United Nations Development Programme (2018) Nigeria was ranked $157^{\text {th }}$ in terms of human development index which has 0.532 score. Also, Nigerian unemployment, underemployment and youth unemployment/underemployment rate according to National Bureau of Statistics (2019) stood at 23.1\%, 20.21\% and $55.4 \%$ respectively. Based on the above statistics together with high rate of corruption especially in government owned institutions, policies inconsistencies, lack of governmental will, insecurity and high level of debt own by the Federal even to the State Government in Nigeria, it is therefore very obvious that Nigeria as a country has been over the years negatively affected by globalization with little benefits.

More so, in regards to the above statistics, Agreement (2011) expressed that globalization is an economic monster aim at wiping away nations' sovereignty in regards to socio-economic and political autonomy. However, our purpose in this paper is not actually to put forward the nature of globalization as a concept or bear out that globalization is harmful or beneficial to countries but rather to show how it has affected the government and the political environment of Nigeria as a country and the managerial implication as well as the individual implication of this impact of globalization. Thus, the center of attention of this study is to critically examine the influence of globalization on the political environment as well on the government of Nigeria and its general implication on organization, managerial effectiveness and on the individual.

\section{LITERATURE REVIEW}

\section{The Concept of Globalization}

This publication is licensed under Creative Commons Attribution CC BY

http://dx.doi.org/10.29322/IJSRP.11.05.2021.p11349
As earlier mentioned, the concept of globalization is very complex and multifaceted; hence, Adesoji (2006) articulated it is hard using a particular standard definition due to its multifaceted nature in relation to diverse perspectives and views, however that does not make it ill defined. Ajekiigbe (2004) explain that globalization is an institutional change, brought about in the society by the increase of in-flows of finances, technology and labour as well as the rapid expansion of business corporations across national borders. It has to do with the acceleration and intensification of interaction and integration among persons, organization, and governments of diverse country which affects individual welfare, economic growth, cultural and social system as well as political system throughout the globe (Majekodunmi \& Adejuwon, 2012) which has made the world to become one.

McGrew (2008) expressed that globalization has to do with the amplification of nations' relations socially, worldwide assimilation economically, as well the compression of time and space. It involves the integration of businesses, technology, finances as well as labor across national frontiers or internationally. Thus, globalization basically means the increasing interrelationship, interdependences and interconnectedness between countries, organizations, regions, governments and individuals which bring about free flow of persons, knowledge, ideas, information, finances, technologies as well as goods and services in so doing promote the integration of nations. The major features of globalization includes the interconnection of dependent countries through commerce and financial inflows and outflows; synchronization of the policies guiding the connection between the independent countries, as well as structures creation to enhance dependence and global marketplace formation brought about by information technology advancements.

Globalization is a practice that has to do with the intensification of interdependencies connecting various state markets as well as industries on a global level which has brought about an inclination towards global production, markets as well as competition. Globalization of today is information oriented by combining electronics, computing and telecommunication tools which result in a sophisticated means for acquiring, sharing and storing information, ideas and goods and services. The major characteristics of today's globalization according to Kolodko (2004) include increase in global trade, increase in financial flows and increase of migration of people from one country to another. No other centuries past has witnessed the rate of global trade as well as financial flows and the rate of migration that we are witnessing in today's world.

Globalization is about transformational change with effects on the political, socio-cultural, economic and environmental aspect of every country which is characterized by exceptional quick flows of goods and service, exchange of ideas as well as information, emergence of new social and political movements and associated by extremes: winners take it all which intensify inequalities (Kiggundu, 2002). Globalization major players in the world include the United States, Western Europe and Japan (Kiggundu, 2002). Globalization has notably and drastically lessened and abridged difficulties of carrying out international business. Thus what it does is to reduce the barriers of doing business in a nation to give room to unlimited or unhampered trade internationally, financial and technological flows by providing foreign investors business environment similar to that of the home 
investors (Narula, 2003). It has developed over the years because of the increase in international businesses that transverse national frontiers and covers more than one nation state.

Furthermore, lots of scholars are of the view that globalization most likely started in the nineteenth century which
Ian, Jamie, and Graham (2011) categorized into four phases, however, it is worthy to note that globalization is as old as man when man started moving from one country to another seeking for greener pastures.

Table 1: Phases of Globalization

\begin{tabular}{|c|c|c|c|}
\hline Phases & Periods & Causes & Features \\
\hline Phase 1 & $1830-1890$ & $\begin{array}{l}\text { Transportation through rail } \\
\text { and ocean }\end{array}$ & $\begin{array}{l}\text { Automated production of products as well as } \\
\text { trading across national frontiers }\end{array}$ \\
\hline Phase 2 & 1900-1930 & $\begin{array}{l}\text { Invention of electricity as well } \\
\text { as steel }\end{array}$ & $\begin{array}{l}\text { The materialization of American and European } \\
\text { extracting and manufacturing industries }\end{array}$ \\
\hline Phase 3 & 1948-1970s & $\begin{array}{l}\text { End of World War II and } \\
\text { General agreement on tariffs } \\
\text { and trade }\end{array}$ & $\begin{array}{l}\text { The emergence of US multinationals, the } \\
\text { emergence of triad nations as well as branded } \\
\text { products and the subsequent effort to minimize } \\
\text { trade barriers }\end{array}$ \\
\hline Phase 4 & 1980 till date & $\begin{array}{l}\text { Information and } \\
\text { communication technology, } \\
\text { privatization, consultancy and } \\
\text { automation }\end{array}$ & $\begin{array}{l}\text { Increased in foreign direct investment in least } \\
\text { developed countries, enhanced technological and } \\
\text { transportation tools, improved worldwide media } \\
\text { and branding }\end{array}$ \\
\hline
\end{tabular}

From the above table, the first phase started from $1830-1890$ which was as a result of enhanced transportation through rail and ocean means of transportation that helped in making long distance trade attainable. This stage was characterized by automated production of products as well as trading across national frontiers. Also, the emergence of telegraph and telephone in the late 1800s for communication assisted in sharing of information which lots of corporation took advantage of in managing their businesses characterized this phase. What triggers the second phase is the invention of electricity as well as the production of steel. It got to its height in the first 10 years of the $20^{\text {th }}$ century, when regions controlled by European were seen as good place to set up international subsidiaries. This phase also saw the materialization of American extracting and manufacturing industries. This period is alleged to have ended with economic recession that took place in 1929, that resulted to worldwide depression which made many governments to look inwards towards formulating better policies to enhancing their survival (Ian et al., 2011).

Furthermore, the third phase focused on end of World War II and the general agreement on tariffs and trade which is a legal agreement between countries so as to minimize trade barriers between them and enhance global trade after the end of World War II. This stage saw the emergence of Japan/US multinationals, the emergence of triad nations (Western Europe, US and Japan) as well as branded products and the subsequent effort to minimize trade barriers. As some persons, principally in richer countries, became wealthier and the austerity brought by the war increased, there was massively increased demand for consumer goods from those wealthy countries across borders (Ian et al., 2011).

The last phase is the stage we are living in today triggered by high rate of information and communication technology, privatization, and consultancy as well automation of manufacturing processes that results in mass production of products. Thus, this phase is characterized with changes in technology, like the availability and accessibility of personal computer coupled with the availability of the internet/world wide web, and the increasing use of mobile communications which has affected all sector of the economy both the manufacturing sectors as well as the service sectors, thus, space is no more a challenge because the world today has become a global village. This phase is also characterized with foreign direct investment into developing countries as a result of political as well as economic policies of countries that allowed corporations to take advantage of the advancement in technology. It is also characterized with the adoption of democracy as a choice of societal governance, human rights conventions, environmental conventions, multilateral service, intellectual property and communications (United Nations Development Programme, 1999).

\section{THE CONCEPT OF GOVERNMENT/ POLITICS}

Government is an institution in every independent nation that runs the affair of the country. It is made up of persons charged with maintaining laws and orders in a country. More so, Government has to do with the method of ruling a particular society or a country which involves the condition of ordered rule through a body of people charged with the duty of governing. Every country has an executive body called government, which is responsible for running the public affairs for a country. In general government is basically characterized by mechanisms through which ordered rule is maintained in the country. It is the machinery for making and enforcing collective decisions by means of public action for a society which includes managing the apparatus of government, regulating public affairs, making decisions and directing society, implementation and coordination of policy formation as well as exerting leadership (Blondel, 1990).

Furthermore, politics is a set of activities that is connected with the governance of a nation, or state which involves decisions making that apply to groups of members (Rod and Martin, 2013). It therefore refers to achieving and exercising positions of governance, that is organized control over a human community, particularly a state (Giovanni, 2005). In today modern state, people often form political parties to represent their ideas. Members of a party often agree to take the same position on many 
issues and agree to support the same changes to law and the same leaders. The political environment of a country is influenced by the political organizations such as philosophy of political parties, ideology of government or party in power, nature and extent of bureaucratic influence of primary groups. The political environment has to do with the government of the day, their policies and attitude towards business concerns. Policies embarked upon by governments are a reflection of their ideological orientations as well as economic structure and development (Abolghasem, Kahkha \& Hamed, 2014).

\section{GENERAL IMPACT OF GLOBALIZATION ON GOVERNMENTS AND POLITICAL ARENA}

There has been lots of dispute about the outcome of globalization in terms of its impact on the political environment across national frontiers both positively and negatively. Globalization has been able to bring improved standards of living in both developed and developing countries and improved governance globally by using the governance of the developed world as a standard. All aspects of globalization vis-à-vis industrialization, information and communication technology, global alliances, as well as the worldwide markets are stronger in the developed countries; yet, these factors have a direct influence on the growth of domestic political structures and processes. As a result, Everest (2014) expressed that the fundamental aim of globalization is to enhance socio-economic situation, curb sociopolitical frictions that benefit nations globally.

Obviously it is worthy to highlight that globalization is indeed a good and desirable phenomenon that has helped in integrating various economies into one so that developing countries can as well benefit from the developed economies of the world. Nevertheless, domestic developing countries political structures and governments have been at the receiving end. Regardless of the benefit enjoyed by the reason of globalization, the world super powers are still suppressing developing countries especially Africa countries. Globalization has generally benefited more the developed nations of the world compared to developing nations especially those in Africa. Thus, Adam and Thomas (2017) noted that Germany as country had a trade surplus of $€ 252.9$ billion about 7\% of her Gross Domestic Product in 2016 coming from her export exceeding her imports.

On the general ground, globalization has benefited the government of the Western World more than those of the developing World, especially African Countries. The developed countries of the world are benefiting more from globalization based on the fact most of the international and financial institutions such as the International Monetary Fund (IMF) and the World Bank are controlled by the developed nations such as the United State of America (Shangquan, 2000). Due to this, developed nations intentionally or unintentionally formulate policies so as to control as well encourage globalization. Though IMF is essentially one of the most influential institutions internationally as it can make and enforce economic policies on its member government, America still heavily influences and determines the content of the IMF conditionality agreement (Oatley \& Yackee, 2004). Thus, the American government uses their influence on the IMF to formulate policies that further enhances their benefit through globalization.
Globalization has been able to give more privilege to the developed world to benefit more and to exploit other less developed countries of the world through the provision of financial aids and borrowing using the World Bank and IMF. As we all know these financial bodies do not have projects through which they earn their funds but are majorly funded by the US and the EU. Thus if we critically analyzed it, is not actually these financial institution that actually fund weaker countries but those countries that are funding those institutions. More so, these developed countries knew that the debt burden given to the less developed countries will keep them pleading on their knees in the verge of misunderstanding between them as the Bible says in Proverbs 22 vs 7 in the second part: "the borrower is a servant to the lender". On a specific note globalization has been used by so called world power to weaken political structures of African countries; this is because they have instilled the spirit of selfishness among elites of African countries (Everest, 2014). By tradition, an African man is a social being who loves to share with entire community but today this good value is no longer there due to globalization. What we now see today are political leaders' as well governmental officials who embezzle public funds for selfish purposes at the detriment of the masses.

\section{GLOBALIZATION EFFECTS ON THE NIGERIAN GOVERNMENT AND POLITICAL TERRAIN}

Nigeria as a country has not been spared from the phenomenon of globalization. Even though, the benefits that are supposed to be enjoyed from taking part in globalization have not been so pronounced, the fact remains that Nigeria has become more connected and integrated with the global political system than before. The Nigerian government is one of the governments in the world that is highly dependent on external trade especially that of crude oil due to the fact it is her major source of income, thus the reason for fully embracing globalization and all its aspects.

More so, one aspect globalization has affected the government of Nigeria, is in the area of democracy. In the last few decades the world has witnessed an extraordinary rise in globalization especially in the spread of democracy and Nigeria is one of the beneficiaries. The word democracy is very synonymous with globalization politically which touches various aspects of the society (Scholte, 2005). Scholte (2005) further expressed that the increase of democratic governance that has been on the rise after the world war was able to bring down military and communist regimes globally. By the reason of globalization, Nigeria today is practicing democratic system of governance with all its accrued benefits. More so, another area globalization have impacted so much on the political terrain of Nigeria and its governance is global governance which has to do with the growth of both specialized and general international organizations such as the United Nations, and African Union as well as Economic Community of West African States (ECOWAS) which Nigeria is a member. The influence of the above organizations is to build a process, where the organizations are able to determine and dictate what happens in the governance of member states (Oji \& Ozioko, 2011). Today Nigeria being a member of these organizations, one area its impact is being felt is in human rights protection. Due to the internationalization of human rights, Nigerian Government 
cannot just make policies that are detrimental to her citizens as well as foreigners but must conform to international standards.

Another aspect globalization has affected the government of Nigeria is in the area of foreign direct investment as well as increase of multinational enterprise in Nigeria. If not for globalization in terms of foreign direct investment Nigeria would not have been where it is today been the Giant of Africa. This presence of multinational corporation is been enhanced by the changes in the industrial societies brought about by an unprecedented speed, influenced mainly by globalization in terms of transfer of technology, information, and social media globally. No one can deny the importance of multinational corporations in the current global business environment. Nigeria as a country can enjoy varieties of products, services and facilities, brought to their doorsteps; there is creation of more jobs for the populace; the nation's pool of skills are best utilized and put to use effectively and efficiently. They also help in enhancing the balance of payment of host countries by increasing exports and decreasing imports (Osuagwu \& Ezie, 2013). However, this does not mean that they do not have their negative effect on the host country, in fact Onimode (1982) referred to multinational corporations as monsters that have consistently and systematically stifled political and economic development of the host country. More so, their ability to shape demand patterns and values and to influence the lives of people and policies of governments have raised concern about their role in world affairs (Eluka, Ndubuisi-Okolo \& Anekwe, 2016).

Due to globalization African countries especially Nigeria has become a dumping ground for used and obsolete products. For the past 9 months, Nigeria borders have been closed because of inflow of obsolete products from neighbouring countries as well as to encourage indigenous production. The neigbouring countries are taking advantage of globalization to inject those products that can as well be produced in Nigeria. The so called super powers of the world will produce, use it for very long time, after a while they use neighbouring countries as a channel to bring those products to Nigeria, making our country a dumping ground. However, one of the protocols guiding ECOWAS is that no member state is allowed to export into another state what it does not produce. Thus, by closing the Nigerian borders, the government is encouraging local production of goods and services for her populace.

More so, due to globalization, Nigerian government over the past 9 years have been suffering from insurgency such as the Boko Haram because of their affiliation to international terror groups such as the ISIS in the Middle East. When Boko Haram started their operation some few years ago specifically in July 2009 in Bauchi which spread to other part of the North-East geopolitical zone, leaving hundreds of followers, Nigerian law enforcement officers, and civilians dead (Reinert \& Garçon, 2014), then it looks as if it was a joke but since then till now thousands of lives have been lost and has cost Nigeria government billions of dollars in trying to curb their operations. They have also brought a lot of instability to the government of Nigeria especially those of the North-East which has drastically reduced government performance in the affected area.

Another major focus of globalization is the amassment of wealth through private initiatives, rather than attaching value to accumulation for the aspirations of all the citizens within the country which cripples democracy (Agreement, 2011). There is a strong indication that the impact of globalization is most felt through the extent to which politics everywhere are now essentially market-driven. It is not that governments are now unable to run their states, but to survive; they must increasingly manage national politics in such a way as to adapt them to the pressures of international market forces which has led to political globalization (Oji and Ozioko, 2011). On the reason why the government of developing countries especially those in Africa are unable take advantage of globalization, Barry (2010) expressed that government of Africa countries are still heavily relying on sales of natural resources, lack diversification as well as stumpy investment in human capital development which has led to the failure of government of these African countries in taking advantages of globalization. This is even more serious in Nigeria where the government of Nigeria has refused to diversify the country's economy from oil based economy to industrialized economy given her well wither and prowess as well as human and natural endowment.

\section{GLOBALIZATION IMPLICATIONS FOR ORGANIZATIONS}

Globalization has been able to make organizations have access to mass markets and increased sales, achieved economies of scale and reduced cost, provides access to resources in terms of labour, raw materials, technologically as well as financially globally. These accesses brought by globalization provide the environment for organizations specifically for managers to make on time decision with the amount of information resources at their disposals. Globalization has brought with it new sophisticated technology, hence managers must frequently and continuously learn about new ways of doing things and make sound decisions in accordance with them to improve their organizations' performance. Globalization has brought enormous opportunities to organizations and managers as it provides access to larger market globally. It will only be a problem to organizations and managers if they are unable to create more innovative solutions as well possess the capability to always align themselves to changes in the global environment.

The operations of organization over the last two decades been it small or large, profit or non-profit, publicly or privately owned organizations have changed drastically. A lot of organizations have restructured, and realigned their operations, have become more strategic, adopted new and modern technology and developed their employees more so as to meet needs of today's customers and satisfy them better. The business world today has become more competitive and customers have more access to variety of products all over the world with a single click the customers can get whatever they want at the comfort of their home since the world has become a global village. Thus globalization has made the business environment to be more difficult for organization especially the domestic ones that do not have the financial muscles to compete with those of the foreign counterparts. Consequently, nowadays managers' job has become very tasking. Managers that do not have the will to change policies and strategies will not be able to operate in today's globalized business environment.

Globalization influence on the government of any given country also has a way of affecting the business organizations and managerial decisions. This is because government decisions at all 
levels are important tools which influence the business environment of all organizations (Ian et al., 2011). Political stability as well as policies enacted by government can either mar or make an organization and its management. Thus, Mark and Nwaiwu (2015) expressed that not only the political environment poses direct risks to business organizations but also have the potential to promote or inhibit market competition, and political mismanagement can turn natural or human-made events into catastrophes that can affects organizational success. Also, Andoh (2007) expressed that changes in the political environment arising from changes in government policies due to globalization, would influence the ability of business organizations as well as managers in achieving their stated objectives. The political environment defines the legal and regulatory parameters within which organizations must operate. Therefore, the direction and stability of the political environment should be a major consideration for managers in formulating organizational strategy in today's globalized world they operate in.

\section{GLOBALIZATION IMPLICATION ON INDIVIDUAL}

Globalization has also played important roles on individuals across the globe specifically in Nigeria. Globalization in terms of foreign direct investment and multinational enterprise has brought a lot of employment to the citizens of this country as well raising their standard of living. For many developing nations, globalization has led to an improvement in standard of living through the provisions of better transportation system, better health care services, and better education system.

More so, globalization has brought to the individual the ability to access product globally at a cheaper rate, have access to wider choice of products and get access to better quality of products. Therefore, looking at it from the individual level, globalization has affected the standard of life and quality of life of individuals and families globally especially for those who live in developing nations. However, a number of multinational companies have been accused of offering very poor rates of pay and forcing employees to work in sweatshop conditions that is not attainable in their home countries; others have been as well accused of employing child labour, which affects their education (Ian et al., 2011).

\section{CONCLUSION AND RECOMMENDATIONS}

Globalization has made the world of today to become a global village where one can eventually get anything in need within a blinks of the eye due to information and technological advancement. Globalization has succeeded in compressing the world into a village where relations between different individuals, organizations and government actually look as if they are in one village. It has and is still shaping the decisions of individual, organizations as well as government of every nation state. The case of the corona virus pandemic that has bedeviled the world today, has shown that government all over the world are interrelated, interconnected and interdependent in one way or the order. More so, globalization is very important to every government as well to every organization, this is because, no government is self-sufficient, no government can exist in a vacuum and no government is an island of itself, thus the need for integration brought by globalization. However Nigeria as a country have not been able to benefit from the process of globalization as it ought to due to corruptions, weak institutions and lack of governmental will to do what is right.

Furthermore, though globalization has some negative consequences, they cannot be compared to the benefits it has in store for developing countries such as Nigeria if it is harnessed appropriately by the Nigerian government by putting right policies in place and taking advantage of today's globalization. Thus, for globalization to eventually benefit the Nigerian government, it must have certain levels of capacity that will enable it to effectively and efficiently participate in it. The government of Nigeria can benefit more from globalization by developing policies that will bring about improvement of the nation's competitive advantage in the global market by avoiding all kinds of foreign exploitation as well as all forms of corruptions at all level. Nigeria government should as well improve the democratization process in the country as its current form is not encouraging at all. Also Nigerian government must reduce and avoid the rate at which it is borrowing. The exceptional debt burden of Nigeria is well known which often places Nigeria at the receiving end. The most annoying part of this borrowing by government is that the purpose of which they engaged in it is not even yielding tangible development in the country but it is been used for selfish interest, hence the rate of borrowing in the country should be minimized.

\section{REFERENCES}

[1] Abolghasem, O., Kahkha, A., \& Hamed, A. (2014). Corporate entrepreneurship and firm performance important role of small and medium enterprise. International Journal of Academic Research in Business and Social Sciences, 4(6), 23-47.

[2] Adam, N., \& Thomas, A. (2017). Germany's global trade surplus hits record in 2016. Wall Street Journal, 3(5), 1-16.

[3] Adesoji, A.A (2006). Globalization of the media and the challenges of democratization in Nigeria. Nebula, 3(4), 38-50.

[4] Agreement, L.J. (2011), Globalization and the nation-state: sovereignty and state welfare in jeopardy. US-China Education Review, 2, 243-250

[5] Ajekiigbe, J (2004). Effects of globalization and universal banking in Nigeria. The Guardian, July, 27 and 31.

[6] Andoh, C. H. (2007). Competing effectively: environmental scanning, competitive strategy and organisational performance in small manufacturing firms. Journal of Small Business Management, 38(1), 27-47.

[7] Barry, H. (2010). Globalisation and economic growth in Sub-Saharan Africa. Gettysburg Economic Review, 4(4), 42-86.

[8] Blondel J. (1990). Comparative government: an introduction. New York: Philip Allan.

[9] Eluka, J., Ndubuisi-Okolo, P.U., \& Anekwe, R.I. (2016). Multinational corporations and their effects on Nigerian economy. European Journal of Business and Management, 8(9), 59-67.

[10] Everest, T. (2014). The impact of globalization on domestic political structures in established, transitional and non-democracies. Journal of Good Governance and Sustainable Development in Africa, 2(2), 94-109.

[11] Giovanni, S. (2005). Parties and parties systems: a framework for analysis. Munich: ECPR Press.

[12] Ian, B., Jamie, W. \& Graham, W. (2011). Globalization ,challenges and changes (2nd edi.). New York: Financial Times/ Prentice Hall.

[13] Intriligator, M.D (2003). Globalization of the world economy: potential benefits and costs and a net assessment. Policy Brief, No 33, January, Milken Institute: University of California, Los Angeles. 
[14] Kiggundu, M.N. (2002). Managing globalization in developing countries and transition economies: Building capacities for a changing world. Westpoint CT: Preager.

[15] Kolodko, G.W. (2004). Globalization and catching up of in emerging market economies. Text of Public Lecture delivered at the Nigeria Institute of International Affairs (NIIA) Lagos, Nigeria Friday, July 16.

[16] Majekodunmi, A. \& Adejuwon, K.D. (2012). Globalization and African political economy: the Nigerian experience. International Journal of Academic Research in Business and Social Sciences, 2(8), 189-206.

[17] Mark, J. \& Nwaiwu, J. (2015). Impact of political environment on business performance of multinational companies in Nigeria. Ethiopia International Multidisciplinary Journal, 9(3), 1-10.

[18] McGrew, A. (2008). The logics of economic globalization. New York: Oxford University Press.

[19] Narula, S. (2003). Globalization: India's experience for the African continent. DPMF Occasional Paper, No. 7, Development Policy Management Forum, Addis Ababa.

[20] National Bureau of Statistics (2019). Retrieved from https://www.nigerianstat.gov.ng/

[21] Ngaire, W. (2000). The political economy of globalization. Basingstoke: Macmillan.

[22] Oatley, T. \& Yackee, J. (2004). American interests and IMF lending. Journal of International Politics, 41(3), 415-429.

[23] Oji, E.A. \& Ozioko, M.V.C. (2011). Effect of globalization on sovereignty of States. African Journal Online, 2, 257-270.

[24] Onimode, B. (1982). Imperialism and underdevelopment in Nigeria: the dialectics of mass poverty. London: Zed Press.

[25] Osuagwu, G.O. \& Ezie, O. (2013). Multinational corporations and the Nigerian economy. International Journal of Academic Research in Business and Social Sciences, 3(4), 259-269.
[26] Reinert, M., Garçon, L. (2014). Boko Haram: a chronology. In: Pérouse de Montclos MA: Islamism, politics, security and the state in Nigeria. Vol 2, West African Politics and Society Series. Leiden, Netherlands: African Studies Centre, Institut Français de Recherche en Afrique; 237-245.

[27] Rod, H. \& Martin, H. (2013). Comparative government and politics: an introduction. New York: Macmillan International Higher Education.

[28] Scholte, J. (2005). Globalization: a critical introduction (2nd edi.). Palgrave: Macmillan.

[29] Scholte, J.A. (2000). Globalization: a critical introduction. Basingstoke: Palgrave.

[30] Shangquan, G. (2000). Economic globalization: trends, risks and risk prevention. CDP background paper No. 1. United Nations Development Policy and Analysis Division. Department of Economic and Social Affairs.

[31] United Nations Development Programme (2018). Retrieved from http://hdr.undp.org/en/countries/profiles/NGA

[32] United Nations Development Programme (UNDP). 1999. Human Development Report 1999. New York: Oxford.

[33] World Bank (2019). Retrieved from http://saharareporters.com/2019/06/05/918-million-nigerians-are-extremelypoor-says-world-poverty-clock

\section{AUTHORS}

First Author - Evwierhurhoma, Daniel Ejiroghene Department of Management, Faculty of Management Sciences, University of Port Harcourt, Nigeria, e.daniel.ejiro@gmail.com

Second Author - Dr. E. Amah, Department of Management, Faculty of Management Sciences, University of Port Harcourt, Nigeria., edwinah.amah@uniport.edu.ng 